\title{
Evaluation of Antioxidant Activities and Active Compounds Separated from Water Soluble Extracts of Korean Black Pine Barks
}

\author{
ChangZhe Shen, HongYoung Jun, SungHo Choi, ${ }^{\dagger}$ YoungMan Kim, ${ }^{\dagger}$ EunJoo Jung, GiSu Oh, ${ }^{\S}$ SungJin Joo, \\ SungHyun Kim, and IlKwang Kim* \\ Division of Bio-Nano Chemistry, Wonkwang University, Iksan 570-749, Korea. ${ }^{*}$ E-mail: ilkim@wku.ac.kr \\ ${ }^{\dagger}$ Department of Chemistry, Hannam University, Daejeon 305-811, Korea \\ ${ }^{\ddagger}$ Advanced Analysis Center, KIST, Seoul 136-791, Korea \\ ${ }^{\S}$ Vestibulocochlear Research Center, Wonkwang University, Iksan 570-749, Korea \\ Received January 18, 2010, Accepted September 24, 2010
}

\begin{abstract}
Black pine barks from the southern region of Korea were extracted using pressurized hot water and the water soluble extracts were then separated in a stepwise fashion using a variety of solvents, column chromatography (CC), thin layer chromatography (TLC), and high pressure liquid chromatography (HPLC). The antioxidant activities of each fraction and the active compounds were determined based on the radical scavenging activities of 2,2-diphenyl-1-picrylhydrazyl (DPPH), reductive potential of ferric ion, and total phenol contents. A DPPH test showed that the half maximal effective concentration $\left(\mathrm{EC}_{50}\right.$ value : $\left.6.59 \pm 0.31 \mu \mathrm{g} / \mathrm{mL}\right)$ of the ethyl acetate fraction $(c a .0 .67 \%)$ was almost the same as that of the control compounds and inversely proportional to the value of the total phenol contents. The cell viability of the water extracts was confirmed by methyl thiazol-2-yl-2,5-diphenyl tetrazolium bromide (MTT) with enzyme linked immune sorbent assay (ELISA). Catechin, epicatechin, quercetin and ferulic acid were isolated from the ethyl acetate fraction as active compounds and identified by nuclear magnetic resonance. The antioxidant activity as value of DPPH of each of the separated compounds was lower than the ethyl acetate fraction, and ferulic acid was the lowest among these compounds.
\end{abstract}

Key Words: Black pine bark, Antioxidant activity, Total phenol content, Reductive potential, DPPH

\section{Introduction}

Korean black pine (Pinus thunbergiana: Fig. 1) is a medium sized, irregularly shaped pyramidal tree that can resist the effects of salt spray and saline soil in the shore line better than most other plants. For centuries, Koreans have eaten the needles and bark of pine trees in the spring lean season and prepared medicinal extracts from the endodermis of black pine bark. ${ }^{1}$ Over the past few years, waste barks or solids of pine trees have attracted a great deal of attention in the research arena due to their high potential for use as bio-active compounds, antioxidants, and biomedical resources. ${ }^{2-5}$ Pine bark extracts contain numerous phenol compounds such as flavonoid condensates (proanthocyanidin), ${ }^{6}$ natural antioxidants, ${ }^{7}$ and anti-aging substances. ${ }^{8}$ Recently, procyanidin-rich extracts (flavonoids mixture) from pine (Pinus maritima) bark, known as pycnogenol, were reported to have strong antioxidant effects, ${ }^{9,10}$ maintain human circulatory health, ${ }^{11}$ induction of human mammary cancer cell (cancer chemoprevention), ${ }^{12,13}$ and to have the potential for use as an herbal medication with a diverse clinical pharmacology. ${ }^{14-16}$ As a result, pycnogenol is now widely utilized as a nutritional supplement and phytochemical remedy for a variety of diseases. ${ }^{17,18}$ The extract from the bark of Pinus radiata containing vitamin c, Enzogenol ${ }^{\circledR}$, was reported to have beneficial clinical effects such as preventing cardio vascular risk and use as a dietary supplement. ${ }^{19}$ Several studies comparing and evaluating the active compounds in bark from pine have been reported, including: characterization of the components of bark from Japanese pine trees, ${ }^{20}$ phenol composition and antioxidant activities of pine needles, ${ }^{21}$ extraction of poly flavonoids from
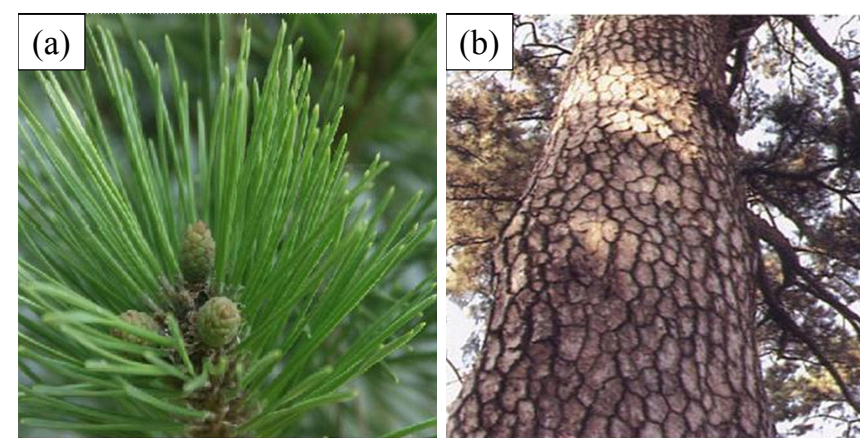

Figure 1. A part photograph of Korean black pine (a): needles, (b): barks.

Pinus radiata bark, ${ }^{22}$ comparison of the antioxidant activity and procyanidin composition, ${ }^{23}$ and relationships between structure (composition) and antiradical activity. ${ }^{24}$

Pine trees native to different soil environments appear to contain different biological active substances, and may contain compounds that have not yet been described. Therefore, detailed studies of the activity of antioxidants in the active compounds obtained from the barks of Korean black pine to determine if they are useful as herbal medications and functional foodstuffs are warranted. In this study, the barks of Korean black pine were extracted using pressurized hot water to avoid solvent toxicity. Stepwise separation of the active compounds was then performed by TLC, CC, and HPLC. The antioxidant activities of single active compounds and water crude extracts were then determined based on a DPPH test, reductive potential power, and total phenol assay (TPA). In addition, the effects on cell 
viability were assessed by a MTT assay. Three polyphenols and one phenolic acid were separated and identified by Fourier transform nuclear magnetic resonance spectroscopy (FT-NMR). The order of the antioxidant power was as follows: catechin $\simeq$ epicatechin $>$ quercetin $>>$ ferulic acid.

\section{Experimental}

Chemicals and materials. The bark of black pine was collected from the mountains of the Iksan city at South Korea. Butylated hydroxytoluene (BHT), butylated hydroxyanisole (BHA), tris (hydroxyl methyl) aminomethane hydrochloride (Tris-HCl), trichloro acetic acid, Folin-Ciocalteu reagent, ascorbic acid, sodium hydroxide $(\mathrm{NaOH})$, potassium dihydrogen phosphate, potassium ferricyanide, iron (II) chloride $\left(\mathrm{FeCl}_{2}\right)$, iron (III) chloride $\left(\mathrm{FeCl}_{3}\right)$, hydro chloric acid $(\mathrm{HCl})$, sodium carbonate $\left(\mathrm{Na}_{2}\right.$ $\mathrm{CO}_{3}$ ), vitamin E, MTT, and DPPH were purchased from SigmaAldrich Co. (St. Louis, MO., USA).

The organic solvents, such as acetonitrile (AN), dichloromethane (DCM), ethyl ether (EE), ethyl acetate (EA), ethanol $(\mathrm{EtOH})$, chloroform $\left(\mathrm{CHCl}_{3}\right)$, butanol $(\mathrm{BuOH})$, and dimethyl sulfoxide (DMSO) were used without further purification as purchased from Sigma-Aldrich Co. Silica gel 60 (0.04 - 0.063 $\mathrm{mm})$ and silica gel $60 \mathrm{~F}_{254}$ TLC sheets $(20 \times 20 \mathrm{~cm})$ were purchased from Merck \& Co., Inc. (Whitehouse Station, NJ., USA).

Instruments. A BioTek PowerWave microplate spectrometer (Winooski, VT., USA) equipped with a 96 well plate and the Gen 5 Data Analysis software was used for the DPPH tests by ELISA. A Hanil centrifuge (Hm 150 IV, Seoul, Korea) and a revolving evaporator with an EYELA digital water bath (SB-1000, Tokyo Rikakikai Co., LTD.) were used for extraction of the effective compounds in black pine barks. A Fourier-transform nuclear magnetic resonance (FT-NMR) spectrometer (JEOL Ltd. Eclipse 500, Tokyo, Japan) was used to identify the structure of the active compounds. Preseparation was conducted by column (id. $4 \mathrm{~cm}$, L. $40 \mathrm{~cm}$ ) chromatography using organic solvents and a Waters preparative chromatography system (Delta Prep, Milford, MA., USA) equipped with a photodiode array detector, prep LC controller, YMC Hydrosphere $\mathrm{C}_{18}$ column $(20 \times 250 \mathrm{~mm}$, particle size $5 \mu \mathrm{m}$, pore size $120 \AA)$, and Empower 2 Build 2154 software was used for separation of the final active compounds.

Extraction and separation. Chopped and dried barks of Korean black pine were ground into a powder for complete extraction. Water soluble crude extracts were obtained from the powder $(2.0 \mathrm{~kg})$ using pressurized hot water $\left(80^{\circ} \mathrm{C}\right)$, which was then evaporated under vacuum to yield $76 \mathrm{~g}(3.8 \%)$ of water crude extracts. Next, the water extracts were dissolved in distilled water and partitioned with $n$-hexane, ethyl acetate, and $n$-butanol successively in order of their polarity. The yields of the solvent partition from the crude extract were as follows: $n$-hexane fraction $0.016 \mathrm{~g}(0.021 \%)$, ethyl acetate fraction $13.3 \mathrm{~g}(17.5 \%)$, $n$-butanol fraction $20.9 \mathrm{~g}(27.5 \%)$, and water layer $38.9 \mathrm{~g}$ $(51.2 \%)$. The ethyl acetate fraction showed the highest antioxidant activity upon DPPH assay. A portion (1.28 g) of the EA fraction $(13.3 \mathrm{~g})$ was taken and further subjected to separation by silica gel 60 column chromatography. Stepwise gradient elution with $\mathrm{EE}: \mathrm{MeOH}(9: 1 \rightarrow 0: 1, \mathrm{v} / \mathrm{v})$ gave 49 fractions, with fraction

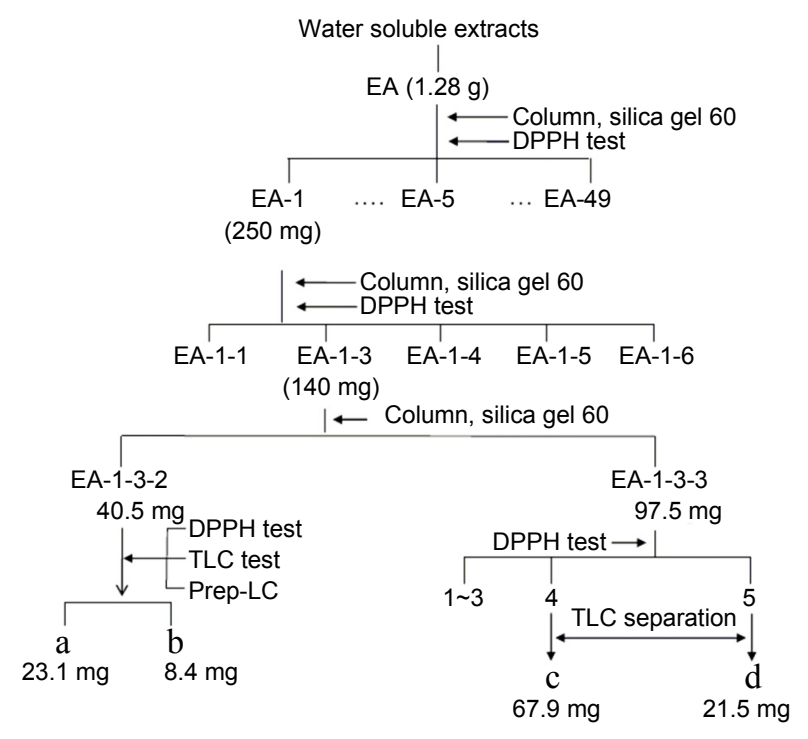

Scheme 1. Stepwise separation processes for active compounds from ethyl acetate layer.

EA-1 (250 mg, 19.5\%) showing strong antioxidant activity. The EA-1 fraction was chromatographed on a silica gel 60 column $(\mathrm{L}: 30 \mathrm{~cm}$, I.D. $1 \mathrm{~cm})$ with a mixed eluant EE: $\mathrm{CHCl}_{3}(9: 1 \rightarrow 0: 1$, $\mathrm{v} / \mathrm{v})$ to give six fractions. Next, the obtained fraction EA-1-3 $(140 \mathrm{mg})$ was processed again on the same column using the mixed eluant, EE: $\mathrm{CHCl}_{3}(7: 3)$, which yielded three fractions, EA-1-3-1, EA-1-3-2, and EA-1-3-3. The stepwise separation of EA-1-3-2 and EA-1-3-3 is outlined in detail in Scheme 1 except for the fraction EA-1-3-1 of a small quantity and low antioxidant activity.

Isolation of the active compounds. A Prep LC system was used to separate fraction EA-1-3-2 (40.5 mg), which had the greatest antioxidant activity among the three fractions, using a mixture of $\mathrm{H}_{2} \mathrm{O}: \mathrm{AN}(9: 1 \rightarrow 5: 5, \mathrm{v} / \mathrm{v})$ applied at a flow rate of 4.0 $\mathrm{mL} / \mathrm{min}$ through a Hydrosphere $\mathrm{C}_{18}$ column. The separated peaks observed at wavelengths of $215 \mathrm{~nm}$ and $254 \mathrm{~nm}$ were inspected by TLC at EA : $\mathrm{CHCl}_{3}(1: 1)$ mixture system. The separation of fraction EA-1-3-3 (97.5mg) was conducted by TLC. Fraction EA-1-3-3-4 which had the greatest antioxidant activity among the five fractions of EA-1-3-3 was concentrated in methanol and developed using a carrier solvent system (AN : $\mathrm{DCM}=1: 1$ ). The fraction EA-1-3-3-5 was concentrated in methanol and loaded on to a TLC plate, and developed using a solvent mixture system (AN : $\mathrm{DCM}=85: 15)$.

Free radical scavenging activity (DPPH test). The reaction mixture consisted of $1.0 \mathrm{~mL}$ of $0.5 \mathrm{mM} \mathrm{DPPH}$ and $1.0 \mathrm{~mL}$ of $0.05 \mathrm{M}$ Tris- $\mathrm{HCl}$ buffer ( $\mathrm{pH} 7.4$ ) in $1.0 \mathrm{~mL}$ of ethanol. ${ }^{25}$ The absorbance of the mixture was measured at $517 \mathrm{~nm}$ exactly 30 min after the addition of different concentrations of extracts (concentration ranging from $0.5 \mu \mathrm{g} / \mathrm{mL}$ to $100 \mu \mathrm{g} / \mathrm{mL}$ ). The DPPH radical scavenging activity of the extracts was expressed as the percentage decrease in the absorbance compared with the control.

Free radical concentration $(\%)=\left(\mathrm{A}_{1} / \mathrm{A}_{0}\right) \times 100$

where $A_{0}$ is the absorbance of the control reaction and $A_{1}$ is the 
absorbance of the sample. The uncompensated equation (1) was simple and matched the experimental data.

Reductive potential test. The reductive potential of the extracts was measured using a modification of the method described by Oyaizu. ${ }^{26}$ A $250 \mu \mathrm{L}$ sample containing different concentrations of pine bark was mixed with $250 \mu \mathrm{L}$ phosphate buffer $(0.2 \mathrm{M}, \mathrm{pH}=6.6)$ and $250 \mu \mathrm{L}$ potassium ferricyanide $(1 \%)$. The mixture was then incubated at $50{ }^{\circ} \mathrm{C}$ for $20 \mathrm{~min}$. Next, a portion $(250 \mu \mathrm{L})$ of trichloroacetic acid $(10 \%)$ was added to the mixture, which was subsequently centrifuged for $10 \mathrm{~min}$ at $3000 \mathrm{rpm}$. The upper layer of the solution $(600 \mu \mathrm{L})$ was mixed with $\mathrm{FeCl}_{3}(120$ $\mu \mathrm{L}, 0.1 \%$ ), and the absorbance was measured at $700 \mathrm{~nm}$ in a 96 wells microplate. A higher absorbance of the reaction mixture indicated a greater reductive potential power.

Total phenol content measurements. The total amount of phenol compounds in the pine bark extracts was measured using a modification of the method described by Spanos and Wrolstad. ${ }^{27}$ Briefly, $150 \mu \mathrm{L}$ of the extracts were appropriately diluted to different concentrations. Each sample was then oxidized with $750 \mu \mathrm{L}$ of freshly diluted Folin-Ciocalteu reagent, which is a mixture of phosphomolybdate and phosphotungstate used for the colorimetric assay of phenol and polyphenol antioxidants. ${ }^{28}$ Folin-Ciocalteu reagent works by measuring the amount of the substance being tested that is required to inhibit the oxidation of the reagent. ${ }^{29}$ This reaction was neutralized by adding $600 \mu \mathrm{L}$ of $7.5 \% \mathrm{w} / \mathrm{v}$ sodium carbonate and then vortexing the samples for $20 \mathrm{sec}$. Next, the samples were incubated at $45^{\circ} \mathrm{C}$ for $20 \mathrm{~min}$ and the absorbance of the resulting blue color was measured at $765 \mathrm{~nm}$ using a spectrophotometer. The results were expressed as the gallic acid equivalence (GAE).

MTT assay. Cell viability (cytotoxicity) was measured in a 96-well plate using an enzyme linked immunosorbent assay (ELISA). ${ }^{30}$ RAW 264.7 cells were mechanically scraped and plated at $1 \times 10^{5}$ cells/well in 96 well plates containing 100 $\mu \mathrm{L} /$ well of Dulbecco's modified eagle medium (DMEM) with $10 \%$ heat- inactivated fetal bovine serum (FBS). Samples were incubated overnight. The concentrated water extract was dissolved in DMSO to give a final concentration not exceeding $0.1 \%$. After overnight incubation, the test material was added and the plates were incubated for $24 \mathrm{~h}$. The cells were then washed once before adding $50 \mu \mathrm{L}$ of FBS-free medium containing 5 $\mathrm{mg} / \mathrm{mL}$ MTT. After $4 \mathrm{~h}$ of incubation at $37^{\circ} \mathrm{C}$, the medium was discarded and the formazan blue formed in the cells was dissolved in $100 \mu \mathrm{L}$ of DMSO. The optical density of the untreated control cells measured at $540 \mathrm{~nm}$ was taken as $100 \%$ viability.

Statistical analysis and data evaluation. All data are expressed as the mean \pm S.E.M. of at least three experiments and were analyzed statistically using Microsoft Excel's ToolPak to acclimate the t-test with equal variances. Data were considered to be statistically significant if the probability value was 0.05 or less $(\mathrm{p} \leq 0.05)$. Some data treatments and figures were processed using the Origin Pro 7.5 data analysis and graphing software.

\section{Results and Discussion}

Antioxidant activities of solvent layers. The antioxidant activities of solvent layers separated from the water soluble extracts of Korean black pines were measured using the DPPH method

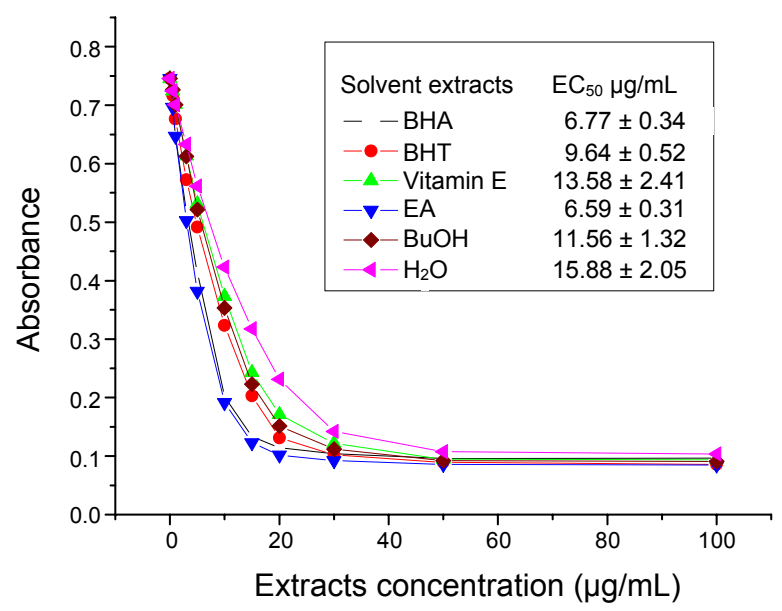

Figure 2. The radical scavenging activities (DPPH test) of solvent extracts.

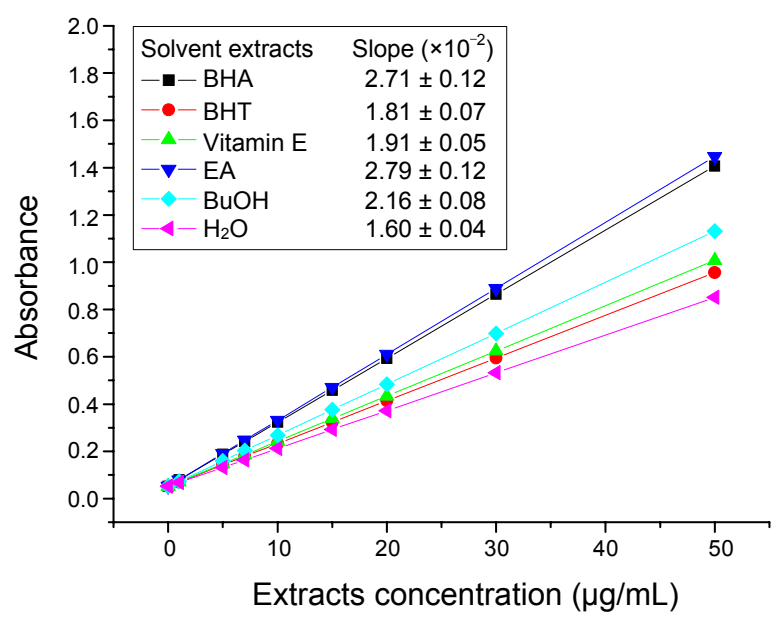

Figure 3. The Fe(III) reductive potential power of solvent extracts.

and reductive potential tests. The DPPH results are shown at Fig. 2 with the $\mathrm{EC}_{50}$ values and compared with the control standards (BHA, BHT and vitamin E). The DPPH tests revealed that the hexane layer $(0.021 \%)$ separated from the water extracts showed only a very low activity $\left(\mathrm{EC}_{50}>200 \mu \mathrm{g} / \mathrm{mL}\right)$. Conversely, the ethyl acetate $\left(\mathrm{EC}_{50}=6.59 \pm 0.31 \mu \mathrm{g} / \mathrm{mL}\right)$ and butanol $\left(\mathrm{EC}_{50}=\right.$ $11.56 \pm 1.32 \mu \mathrm{g} / \mathrm{mL}$ ) layers showed the antioxidant activity of the same level as the control standards $\left(\mathrm{BHA}, \mathrm{EC}_{50}=6.77 \pm 0.34\right.$ $\mu \mathrm{g} / \mathrm{mL}$; BHT, $\mathrm{EC}_{50}=9.64 \pm 0.52 \mu \mathrm{g} / \mathrm{mL}$; vitamin E, $13.58 \pm 2.41$ $\mu \mathrm{g} / \mathrm{mL})$. Evaluation of the reductive potential results revealed that the activity effect and concentration of the sample were well correlated at concentrations of less than $50 \mu \mathrm{g} / \mathrm{mL}$. Additionally, deposition of $\mathrm{Fe}^{2+}$ at concentrations greater than $50 \mu \mathrm{g}$ / $\mathrm{mL}$ influenced determination of the activity. The reductive potential power was determined from the linear slope shown in Fig. 3. The EA and $\mathrm{BuOH}$ layers showed a higher slope value of $2.79 \times 10^{-2}$ and $2.16 \times 10^{-2}$ than the standard BHA $(2.71 \times$ $10^{-2}$ ). Based on these results, the order of antioxidant activities was $\mathrm{EA}>\mathrm{BuOH}>\mathrm{H}_{2} \mathrm{O}$, and pressurized hot water extraction was sufficient to collect the antioxidants from bark of black pine.

Antioxidant activities of fractions obtained by stepwise separation. The antioxidant activities of the fractions separated step- 
Table 1. An evaluating data for the antioxidant activities of stepwise separation fractions and control standards

\begin{tabular}{lccr}
\hline \multirow{2}{*}{ Fractions } & DPPH method & $\begin{array}{c}\text { Reductive } \\
\text { potential }\end{array}$ & \multicolumn{1}{c}{ Total phenol } \\
\cline { 2 - 4 } & $\mathrm{EC}_{50}(\mu \mathrm{g} / \mathrm{mL})$ & slope $\left(\mathrm{A} / 10^{2}\right)$ & $\left(\mathrm{GAE}^{*} \mathrm{mg} / \mathrm{g}\right)$ \\
\hline EA-1 & $11.26 \pm 1.40$ & $3.82 \pm 0.01$ & $428.31 \pm 0.83$ \\
EA-2(5 30) & $34.72 \pm 5.77$ & $<0.3$ & $64.24 \pm 0.90$ \\
EA-3(31 49) & $>100$ & $<0.5$ & $32.81 \pm 0.58$ \\
EA-1-1 & $46.83 \pm 1.23$ & $0.81 \pm 0.09$ & $112.42 \pm 0.15$ \\
EA-1-2 & $14.52 \pm 1.62$ & $1.04 \pm 0.08$ & $156.00 \pm 0.41$ \\
EA-1-3 & $8.86 \pm 0.37$ & $3.23 \pm 0.01$ & $395.05 \pm 0.45$ \\
EA-1-4 6 & $>50$ & $<0.3$ & $13.21 \pm 0.28$ \\
EA-1-3-2 & $8.97 \pm 0.45$ & $2.57 \pm 0.04$ & $178.28 \pm 0.99$ \\
EA-1-3-3 & $7.66 \pm 0.43$ & $2.89 \pm 0.07$ & $150.26 \pm 1.26$ \\
BHA & $6.77 \pm 0.34$ & $2.71 \pm 0.02$ & $39.21 \pm 0.09$ \\
BHT & $9.64 \pm 0.52$ & $2.81 \pm 0.07$ & $77.16 \pm 0.16$ \\
Vitamin E & $13.58 \pm 2.41$ & $1.91 \pm 0.05$ & $20.17 \pm 0.39$ \\
\hline
\end{tabular}

*GAE: gallic acid equivalence $(\mathrm{mg} / \mathrm{g})$.

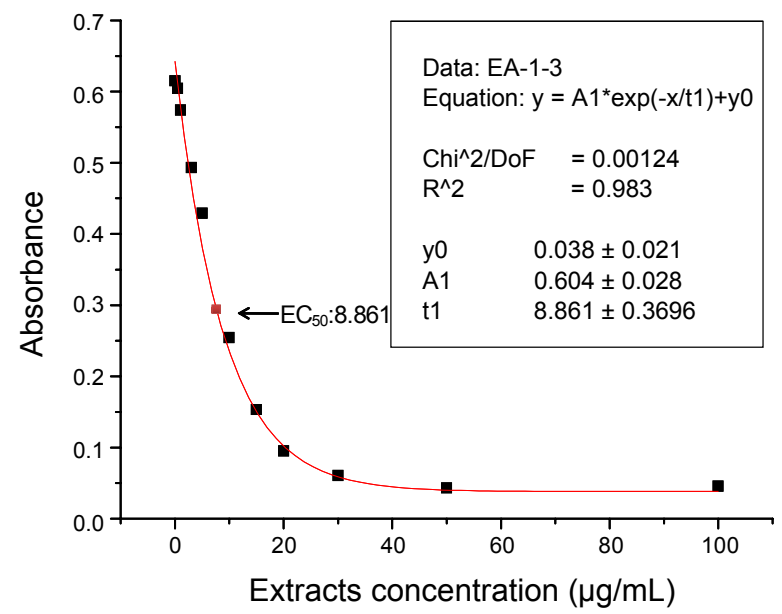

Figure 4. Plot of free radical scavenging activity (DPPH) vs. concentration of fraction EA-1-3 obtained from black pine bark.

wise by silica gel column chromatography were measured by $\mathrm{DPPH}$, reductive potential (RP), and total phenol tests. As shown in Table 1, the EA-1 (DPPH EC $50=11.26 \pm 1.4 \mu \mathrm{g} / \mathrm{mL}$, RP slope $=0.0382 \pm 0.0001, \mathrm{TP}$ GAE $=428.31 \pm 0.83 \mathrm{mg} / \mathrm{g}$ ) and EA-1-3 $\left(\right.$ DPPH EC $_{50}=8.86 \pm 0.37 \mu \mathrm{g} / \mathrm{mL}$, RP slope $=0.0323 \pm$ $0.0001, \mathrm{TP}$ GAE $=395.05 \pm 0.45 \mathrm{mg} / \mathrm{g}$ ) fractions showed almost the same antioxidant activity as the control standards BHA, BHT and Vitamin E. Though the control standards BHA, BHT and Vitamin $\mathrm{E}$ have small GAE values of total phenol (BHA: $39.21 \pm 0.09$, BHT: $77.16 \pm 0.16$ ), they are acting as good antioxidant of lower DPPH EC 50 values (BHA: $6.77 \pm 0.34$, BHT: $9.64 \pm 0.52$, Vitamin E: $13.58 \pm 2.41$ ).

Even if the control standards, synthetic BHA and BHT are good antioxidants of low DPPH values, natural antioxidants such as EA-1 and EA-1-3 of high GAE values are more desirable antioxidants containing polyphenols depending on the quantity of hydroxyl (-OH) group on the phenyl rings. The variation in

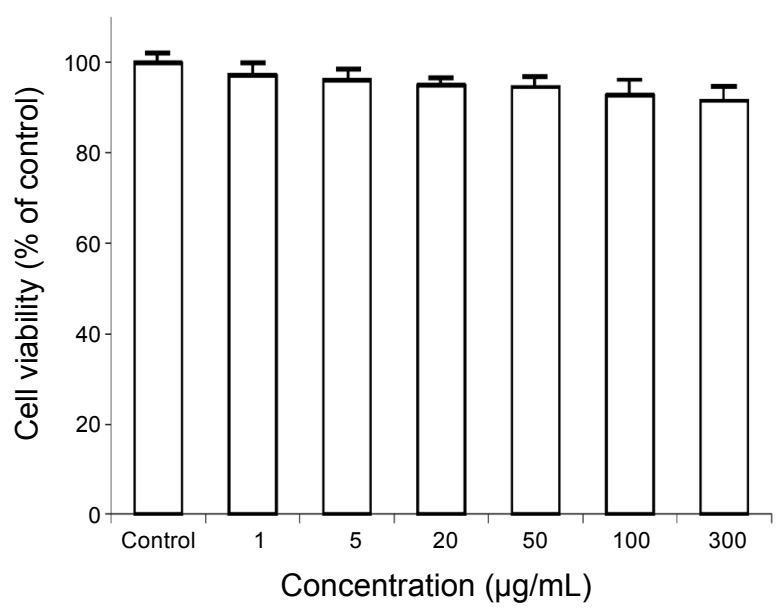

Figure 5. Effect of water soluble extracts on the viability of RAW 264.7 cells ( $48 \mathrm{hrs}$ ). The viability of the cells was measured by MTT assay. The results are expressed as the mean \pm S.E.M. of at least three experiments. $(* \mathrm{p}<0.05)$.

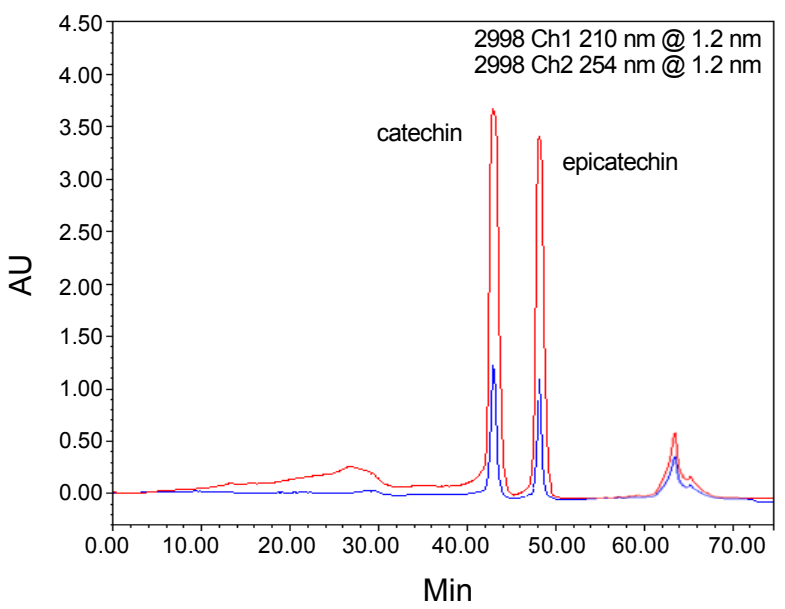

Figure 6. The HPLC chromatogram of catechin and epicatechin obtained from fraction EA-1-3-2.

absorbance as a function of the concentration of fraction (EA1-3) are also shown in Fig. 4.

The MTT assay in Raw 264.7 cells. The cytotoxic effect of the water soluble extracts was determined based on the optical density (OD) value of the formazan after addition of the MTT solution. Fig. 5 shows the OD values as a percentage of the control (distilled water instead of sample) at different concentrations range $(1 \mu \mathrm{g} / \mathrm{mL} \sim 300 \mu \mathrm{g} / \mathrm{mL})$. The cell viability was holded with a high existent probability: $96.7 \%$ at $5 \mu \mathrm{g} / \mathrm{mL} ; 93.2 \%$ at $50 \mu \mathrm{g} / \mathrm{mL} ; 91.8 \%$ at $300 \mu \mathrm{g} / \mathrm{mL}$. The water soluble extracts had relatively no cytotoxic effects on cells at concentrations less than $300 \mu \mathrm{g} / \mathrm{mL}$.

Identification of the active compounds. The two substances were separately collected from fraction EA-1-3-2 $(40.5 \mathrm{mg})$, which was found to have the most intense antioxidant activity by Prep LC. The two strong peaks shown in Fig. 6 were detected using a dual wavelength $(215 \mathrm{~nm}, 254 \mathrm{~nm}) \mathrm{UV}$ detector and identified as catechin (a) and epicatechin (b) by NMR. The broad 
<smiles>Oc1cc(O)c2c(c1)OC(c1ccc(O)c(O)c1)C(O)C2</smiles>

(a) Catechin<smiles>O=c1c(O)c(-c2ccc(O)c(O)c2)oc2cc(O)cc(O)c12</smiles>

(c) Quercetin<smiles>Oc1cc(O)c2c(c1)O[C@H](c1ccc(O)c(O)c1)[C@H](O)C2</smiles>

(b) Epicatechin<smiles>COc1cc(/C=C/C(=O)O)ccc1O</smiles>

(d) Ferulic acid
Figure 7. The structures of isolated antioxidation active compounds from ethyl acetate fractions (EA-1-3-2, EA-1-3-3-4, EA-1-3-3-5).

band of 26 - 28 min and small sharp peak of 62 - 64 min shown in Fig. 6 were considered to be impurities.

The separation of fraction EA-1-3-3 (97.5 mg) was not easy due to the long tail of its developing band; therefore, separate collection was conducted by TLC. A TLC separation method was used for EA-1-3-3-4, which had the greatest activity among the five spots on the TLC plate. The spot EA-1-3-3-4 was concentrated in methanol and then loaded onto a TLC plate and developed using a carrier solvent system $(\mathrm{AN}$ : $\mathrm{DCM}=1: 1)$ in the Latch-Lid developing chamber. The separated compou nd (c), was confirmed to be quercetin by NMR. The spot EA-13-3-5 was concentrated in methanol and developed using a solvent mixture system (AN : $\mathrm{DCM}=85: 15)$ in the developing chamber. The isolated compound (d) was confirmed to be ferulic acid by NMR.

The structures of the isolated compounds were confirmed by comparison with previously published data. ${ }^{31-36}$ The authentic data obtained from the reference standard compounds were as follows. Catechin: ${ }^{32} 4.54 \mathrm{~d}(\mathrm{C}-2), 3.99 \mathrm{~m}$ (C-3), $2.44 \mathrm{dd}(\mathrm{C}-4)$, $2.76 \mathrm{dd}(\mathrm{C}-4), 5.95 \mathrm{~d}(\mathrm{C}-6), 5.82 \mathrm{~d}(\mathrm{C}-8), 6.81 \mathrm{~d}\left(\mathrm{C}-2^{\prime}\right), 6.75 \mathrm{~d}$ $\left(\mathrm{C}-5^{\prime}\right), 6.68 \mathrm{dd}\left(\mathrm{C}-6^{\prime}\right)$. Epicatechin: ${ }^{32} 4.74 \mathrm{~s}(\mathrm{C}-2), 3.22 \mathrm{~m}(\mathrm{C}-3)$, $2.44-2.71 \mathrm{~m}(\mathrm{C}-4), 5.89 \mathrm{~d}(\mathrm{C}-6), 5.73 \mathrm{~d}(\mathrm{C}-8), 6.68 \mathrm{~d}\left(\mathrm{C}-2^{\prime}\right)$, $6.89 \mathrm{~d}\left(\mathrm{C}-5^{\prime}\right), 6.68 \mathrm{~d}\left(\mathrm{C}-6^{\prime}\right)$. Quercetin: ${ }^{33,34} 6.18 \mathrm{~d}(\mathrm{C}-6), 6.40 \mathrm{~d}$ (C-8), $7.67 \mathrm{~d}\left(\mathrm{C}-2^{\prime}\right), 6.87 \mathrm{~d}\left(\mathrm{C}-5^{\prime}\right), 7.53 \mathrm{dd}\left(\mathrm{C}-6^{\prime}\right)$. Ferulic acid: ${ }^{35,36} 6.22 \mathrm{~d}(\mathrm{C}-2), 7.64 \mathrm{~d}(\mathrm{C}-3), 3.87 \mathrm{~s}\left(-\mathrm{OCH}_{3}\right), 6.99 \mathrm{~m}$ (C-2').

The confirmed structures of four active substances (three flavonoids and one phenolic acid) are shown in Fig. 7. Catechin (a), epicatechin(b), and quercetin (c) belong to a large class of flavonoids that have been shown to protect against a variety of diseases, including tumors. Studies have demonstrated that the potent peroxyl radical scavenging abilities of flavonoids contribute to inhibition of lipid peroxidation and the oxidation of LDL. ${ }^{37,38}$ Several flavonoids including the epicatechin family of flavonols are powerful inhibitors of nitration and DNA deamination in vitro. ${ }^{39}$ Feeding rats with quercetin during either the initiation or promotion stage inhibited carcinoma formation in the tongue. ${ }^{40}$ Additionally, quercetin contributed to the protection of neuronal cells from oxidative stress-induced neurotoxicity, such as occurs in Alzheimer's disease. ${ }^{41}$

In this study, water soluble extract, $\mathrm{EA}$, and $\mathrm{BuOH}$ fractions with high antioxidant activity were obtained from the barks of the Korean black pine. The water extract and EA fraction of plentiful polyphenol obtained from black pine barks which represent an inexpensive and diverse source of catechin, epicatechin, and quercetin, are expected to be useful as chemopreventive agents.

\section{Conclusion}

The ethyl acetate fraction of the water soluble extract from the barks of Korean black pine showed almost the same antioxidant activity as the control synthetic compounds (BHT, BHA, and Vitamin E). Substance analysis and antioxidant activity tests conducted via stepwise separation revealed that the effective compounds with antioxidant activity were identified as catechin, epicatechin, quercetin, and ferulic acid. The order of the antioxidants power by DPPH test was as follows: catechin $\simeq$ epicatechin $>$ quercetin $>>$ ferulic acid. This suggested that the derivatives of poly hydroxyl phenols (catechin, epicatechin, and quercetin) were strong and carboxylated phenol (ferulic acid) was weak antioxidant. The total phenol content of the effective fractions was inversely proportional to their $\mathrm{EC}_{50}$ values; the compounds with lower $\mathrm{EC}_{50}$ values for antioxidant activity showed higher total phenol content. It is desirable that doses of the concentrated mixture from the water crude extracts were more effective in antioxidation than doses of single substances. These findings indicate that the polar-hydrophilic properties of these antioxidants allow them to be easily absorbed in vivo. Furthermore, some mixtures of polyhydroxy phenols in the EA fractions showed synergistic increases in antioxidant activity. Because these fractions and mixtures contained abundant antioxidants and showed a lack of toxicity, water-soluble extracts of black pine bark could be applied to a wide range of uses, including cosmetics, food additives, therapeutic materials (chemopreventive agents), and health drinks.

Acknowledgments. This work was supported by Wonkwang University in 2008.

\section{References}

1. Choi, O. J. Utilization and Compounds of Medicinal Plants; Ilweolseogak: Seoul, Korea, 1991.

2. Yesil-Celiktes, O.; Otto, F.; Parlar, H. Eur. Food Res. Technol. 2009, 229, 671.

3. Selga, A.; Torres, J.L. J. Agric. Food Chem. 2005, 53(20), 7760.

4. Cui, Y. Y.; Xie, H.; Wang, J. F. Phytother. Res. 2005, 19(1), 34.

5. Jung, M. J.; Chung, H. Y.; Choi, J. H.; Choi, J. S. Phytother. Res. 2003, 17(9), 1064.

6. Kim, N. Y.; Jang, M. K.; Lee, D. G.; Yu, K. H.; Jang, H. J.; Kim, M. H.; Kim, G. K.; Yoo, B. H.; Lee, S. H. Nutr. Res. Pract. 2010, 4(1), 16.

7. Guri, A.; Kefalas, P.; Roussis, V. Phytother. Res. 2006, 20(4), 263

8. Noda, Y.; Anzai, K.; Mord, A.; Kohen, M.; Shinmei, M.; Packer, L. Biochem. Mol. Biol. Int. 1997, 42(1), 35.

9. Rohdewald, P. Int. J. Clin. Pharmacol. Ther. 2002, 40(4), 158.

10. Macrides, T. A.; Shihata, A.; Kalafatis, N. Wright, P. F. A. Biochem. Mol. Biol. Int. 1997, 42(6), 1249. 
11. Mazur, A.; Bayle, D.; Lab, C.; Rock, E.; Rayssiguier, Y. Atherosclerosis. 1999, 145(2), 421.

12. Packer, L.; Rimbach, G.; Virgili, F. Free Radic. Biol. Med. 1999, 27(5/6), 704 .

13. Huynh, H. T.; Teel, R. W. Anticancer Res. 2000, 20(4), 2417.

14. Watanabe, K.; Matsushita, M.; Matsushita, Y.; Umemoto, T. Koku Eisei Gakkai Zasshi. 2007, 57(5), 605.

15. Gruen, I. U.; Ahn, J. 230th National Meeting of the American Chemical Society, Washington, DC, Aug 28-Sept.1, 2005; American Chemical Society.

16. Son, Y. S. Korean Kongkae Taeho Kongbo, KR 2004063696

17. Tenenbaum, S.; Paull, J. C.; Sparrow, E. P.; Dodd, D. K.; Green. L. J. Atten. Disord. 2002, 6, 49

18. Huynh, H. T.; Teel, R. W. Anticancer Res. 1999, 19, 2095

19. Shand, B.; Strey, C.; Scott, R.; Morrison, Z.; Gieseg, S. Phytother. Res. 2003, 17(5), 490.

20. Kofujita, H.; Ettyu, K.; Ota, M. Wood Sci. Technol. 1999, 33(3), 223.

21. Kang, Y. H.; Howard, L. R. J. Food Sci. Nutr. 2010, 15(1), 36.

22. Soto, R.; Freer, J.; Reyes, N.; Baeza, J. Bol. Soc. Chil. Quím. 2001, $46(1), 41$.

23. Jerez, M.; Selga, A.; Sineriro, J.; Torres, J. L.; Nunez, M. J. Food Chem. 2003, 100(2), 439

24. Jerez, M.; Tourino, S.; Sineriro, J.; Torres, J. L.; Nunez, M. J. Food Chem. 2007, 104(2), 518.

25. Shimada, K.; Fujikawa, K.; Nakamura, T. J. Agric. Food Chem. 1992, 40, 945.
26. Oyaizu, M. Jap. J. Nutr. 1986, 44, 307.

27. Spanos, G. A.; Wrolstad, R. E. J. Agric. Food Chem. 1990, 38, 1565.

28. Singleton, V. L.; Orthofer, R.; Lamuela-Raventos, R. M. Methods Enzymol. 1999, 299, 152

29. Vinson, J.; Zubik, L.; Bose, P.; Samman, N.; Proch, J. J. Am. Coll. Nutr. 2005, 24(1), 44

30. Mosmann, T. J. Immuno Methods 1983, 65, 55.

31. Hugo, E.; Gottlieb, V, K.; Abraham, N. J. Org. Chem. 1997, 62, 7512 .

32. Watanabe, M. J. Agric. Food Chem. 1998, 46, 839.

33. Wawer, I.; Zillinska, A. Magn. Reson. Chem. 2001, 39, 374.

34. Van der Woude, H.; Boersma, M. G.; Vervoort, J.; Rietjens, I. M. Chem. Res. Toxicol. 2004, 17(11), 1520

35. Shih, C. Y.; Dumbroff, E. B.; Thompson, J. E. Plant Physiol. 1989, 89,1053

36. Rahouti, M.; Seigle-Murandi, F.; Steiman, R.; Eriksson, K-E. Appl. Environ. Microbiol. 1989, 55(9), 2391.

37. Castelluccio, C.; Paganga, G.; Melikian, N.; Bolwell, G.; Pridham, J.; Sampson, J.; Rice-Evans, C. FEBS Lett. 1995, 368, 188.

38. Salah, N.; Miller, N. J.; Pagannga, G.; Tijburg, L.; Bolwell, G. P.; Rice-Evans, C. Arch. Biochem. Biophys. 1995, 322(2), 339.

39. Oldreive, C.; Zhao, K.; Paganga, G.; Halliwell, B.; Rice-Evans, C. Chem. Res. Toxicol. 1998, $11(12), 1574$.

40. Markita, H.; Tanaka, T.; Fujitsuka, H.; Tatematsu, N.; Satoh, K.; Hara, A.; Mori, H. Cancer Res. 1996, 56, 4904.

41. Heo, H. J.; Lee, C. Y. J. Agric. Food Chem. 2004, 52(25), 7514. 